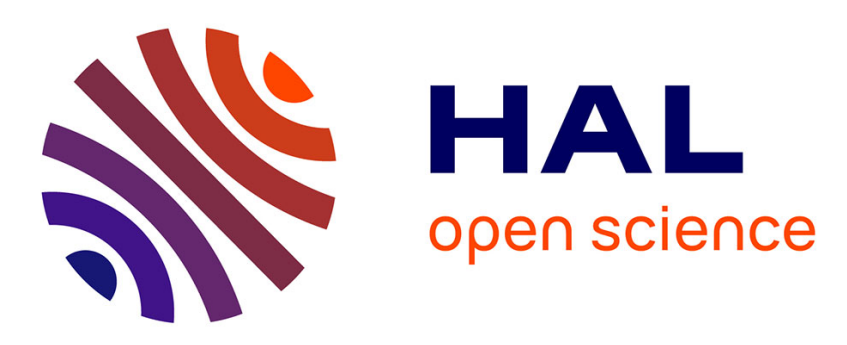

\title{
Plasmids shape the diverse accessory resistomes of Escherichia coli ST131
}

\author{
Arun Gonzales Decano, Nghia Tran, Hawriya Al-Foori, Buthaina Al-Awadi, \\ Leigh Campbell, Kevin Ellison, Louisse Paolo Mirabueno, Maddy Nelson, \\ Shane Power, Genevieve Smith, et al.
}

\section{To cite this version:}

Arun Gonzales Decano, Nghia Tran, Hawriya Al-Foori, Buthaina Al-Awadi, Leigh Campbell, et al.. Plasmids shape the diverse accessory resistomes of Escherichia coli ST131. Access Microbiology, 2020, 10.1099/acmi.0.000179 . hal-03017581

\section{HAL Id: hal-03017581 https://hal.science/hal-03017581}

Submitted on 21 Nov 2020

HAL is a multi-disciplinary open access archive for the deposit and dissemination of scientific research documents, whether they are published or not. The documents may come from teaching and research institutions in France or abroad, or from public or private research centers.
L'archive ouverte pluridisciplinaire HAL, est destinée au dépôt et à la diffusion de documents scientifiques de niveau recherche, publiés ou non, émanant des établissements d'enseignement et de recherche français ou étrangers, des laboratoires publics ou privés. 


\title{
Plasmids shape the diverse accessory resistomes of Escherichia coli ST131
}

\author{
Arun Gonzales Decano'†, Nghia Tran², Hawriya Al-Foori', Buthaina Al-Awadi', Leigh Campbell ${ }^{3}$, Kevin Ellison', Louisse

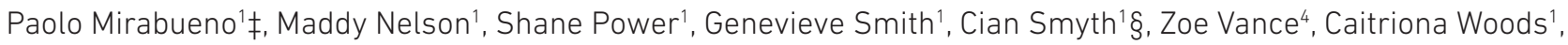 \\ Alexander Rahm²\# and Tim Downing ${ }^{1, *}$
}

\begin{abstract}
The human gut microbiome includes beneficial, commensal and pathogenic bacteria that possess antimicrobial resistance (AMR) genes and exchange these predominantly through conjugative plasmids. Escherichia coli is a significant component of the gastrointestinal microbiome and is typically non-pathogenic in this niche. In contrast, extra-intestinal pathogenic E. coli (ExPEC) including ST131 may occupy other environments like the urinary tract or bloodstream where they express genes enabling AMR and host cell adhesion like type 1 fimbriae. The extent to which commensal E. coli and uropathogenic ExPEC ST131 share AMR genes remains understudied at a genomic level, and we examined this here using a preterm infant resistome. We found that individual ST131 had small differences in AMR gene content relative to a larger shared resistome. Comparisons with a range of plasmids common in ST131 showed that AMR gene composition was driven by conjugation, recombination and mobile genetic elements. Plasmid pEK499 had extended regions in most ST131 Clade C isolates, and it had evidence of a co-evolutionary signal based on protein-level interactions with chromosomal gene products, as did pEK204 that had a type IV fimbrial pil operon. ST131 possessed extensive diversity of selective type 1, type IV, P and F17-like fimbriae genes that was highest in subclade C2. The structure and composition of AMR genes, plasmids and fimbriae vary widely in ST131 Clade C and this may mediate pathogenicity and infection outcomes.
\end{abstract}

\section{DATA SUMMARY}

The following files are available on the FigShare project 'Plasmids_ST131_resistome_2020':

(1) The set of 794 AMR genes derived from [1] are available (with their protein sequence translation) at FigShare at doi: 10.6084/m9.figshare.11961402.

(2) The AMR gene profiles per sample determined by their BLAST sequence similarity results against CARD are available at FigShare at doi: 10.6084/m9.figshare.11961612. This dataset includes the PlasmidFinder results. It also includes other AMR database comparisons (ARG-
ANNOT, ResFinder, MegaRes, VFDB and VirulenceFinder).

(3) The BLAST sequence similarity results for the fim, pil, pap and ucl operons' genes versus 4071 E. coli ST131 assemblies from Decano \& Downing (2019) are available at FigShare at doi: 10.6084/m9.figshare.11961711.

(4) The genome sequences and annotation files for reference genomes NCTC13441, EC958 and SE15, along with the assembled contigs for 83972 and 3_2_53FAA are available at FigShare at doi: 10.6084/m9.figshare.11961813.

(5) The 4071 E. coli ST131 genome assemblies from Decano \& Downing (2019) are available at FigShare at doi:

Received 23 June 2020; Accepted 27 October 2020; Published 18 November 2020

Author affiliations: ${ }^{2}$ School of Biotechnology, Dublin City University, Ireland; ${ }^{2}$ School of Maths, Applied Maths and Statistics, National University of Ireland Galway, Ireland; ${ }^{3}$ Vanderbilt Medical School, Nashville, USA; ${ }^{3}$ School of Genetics \& Microbiology, Trinity College Dublin, Ireland.

*Correspondence: Tim Downing, tim.downing@dcu.ie

Keywords: Escherichia coli; evolution; fimbrial; Genome; infection; plasmid; ST131.

Abbreviations: AMR, antimicrobial resistance; CTX-M, cefotaximase; ESBL, extended-spectrum beta-lactamase; ExPEC, extra-intestinal pathogenic E. coli; HGT, horizontal gene transfer; HMP, Human Microbiome Project; Inc, incompatibility; MGE, mobile genetic element; SIAS, Sequence Identity and

Similarity; SNP, single nucleotide polymorphism; ST, sequence type; TDA, topological data analysis; UTI, urinary tract infection.

†Present address: School of Medicine, University of St., Andrews, UK

‡Present address: National Institute of Agricultural Botany - East Malling Research, Kent, UK

$\S$ Present address: Dept of Biology, Maynooth University, Dublin, Ireland

\#Present address: GAATI Lab, Université de la Polynésie Française, Puna'auia, French Polynesia.

Seven supplementary tables and eight supplementary figures are available with the online version of this article.

000179 @ 2020 The Authors 
$10.6084 / \mathrm{m} 9$.figshare.11962278 (the first 1680 assemblies) and at doi: 10.6084/m9.figshare.11962557 (the second 2391 assemblies).

\section{INTRODUCTION}

Extra-intestinal pathogenic E. coli (ExPEC) cause extensive infections outside the gut, from which they can originate. ExPEC have a wide range of virulence factor (VF) [2-5] and antimicrobial resistance (AMR) genes [6], especially sequence type (ST) 131 from serotypes O25b:H4 and O16:H5 in phylogroup B2 [7]. ST131 causes a substantial fraction of ExPEC and extended-spectrum beta-lactamase (ESBL)-producing cases [8]. ST131's acquisition of key AMR genes encoded on plasmids $[5,9]$ has coincided with its adaptation to new environments $[10,11]$.

ExPEC adherence factors allowing colonisation of different host niches are mainly produced by the Chaperone-Usher secretion pathway, including type 1, P, F1C/S and AFA fimbriae [12-15]. Within ExPEC ST131, fluoroquinoloneresistant Clade $\mathrm{C}$ is the main cause of human infection globally $[16,17]$. Its D-mannose-specific type 1 fimbriae encoded by the fim operon binds the host mucosal epithelium to cause urinary tract and kidney infection [18-21]. The genetic diversity of fimbrial operons beyond fim in Clade C has not yet been examined in large collections of isolates.

ExPEC infection can be associated with a changed microbiome composition [22]. E. coli is the most common initial coloniser of infant intestines [23], where most are commensal [24] and some protect against pathogen invasion [25]. Nonetheless, AMR is prevalent in neonatal units [26] and within-host gene exchange between commensal and pathogenic bacteria may occur [27]. ST131 spreads between mother-infant pairs [28] likely via an oro-faecal transmission route [29], and such colonisation of infants can last for long periods [30]. Consequently, AMR gene screening can inform on treatment strategies [31] and the effect of antibiotics on microbiomes [32].

The ST131 resistome (the set of AMR genes) includes ESBL genes $[33,34]$ allowing third-generation cephalosporinresistance [35] and are associated with three main cefotaximase (CTX-M) resistance alleles: $b l a_{\text {CTX-M-14/15/27 }}$ [36]. Like most AMR genes, these are sandwiched by mobile genetic elements (MGEs) on plasmids and thus can be gained by horizontal gene transfer (HGT) [37-39] or lost if not beneficial $[40,41]$. Of nine common bacterial pathogens, $E$. coli has the most MGEs, including phage-associated ones and transpose $(\operatorname{tnp} A)$ genes [42]. Diverse pathogenic bacteria share MGEs [43-45] and HGT may worsen nosocomial outbreaks [46-48]. Plasmids common to ST131 often have ISEcp1, IS903D and IS26 elements [49] encoding tnpA flanked by short inverted repeats, typically with ESBL genes. Such ESBL genes can be chromosomally transferred and may form part of the core resistome [50].

Fluctuating antibiotic exposure, host type, anatomical niche and immunity mean that resistomes vary [51]. Conjugation, recombination and MGEs help shape ST131 resistome dynamics $[2,11,52-55]$. ST131's plasmids typically are from incompatibility (Inc) groups F, I1, N and A/C [56-58]. Some plasmids in ST131 encode genes for post-segregation killing and stable inheritance to ensure their propagation, but these genes can be lost or may recombine with other plasmids [58-60]. As a result of this mixing and their extensive array of MGEs, plasmids may rearrange extensively even within a clonal radiation [61, 62]. Plasmids may also impair cell reproduction due to the energetic cost of their replication and maintenance, so conjugation and recombination could allow gene dosage optimisation and gene expression coordination.

There is extensive evidence of AMR gene conjugation in the gut between species including E. coli [63-66], and also between its STs, such as: transfer of a bla $a_{\text {CTX-M-1 }}$-positive Incl1 plasmid among ST1640, ST2144 and ST6331 in a single patient's gut [67]; a bla ${ }_{\text {OXA-48 }}$ gene on a K. pneumoniae IncL/M-type plasmid from ST14 to ST666 [68] and from ST648 to ST866 [69]; a $113.6 \mathrm{~kb}$ IncF plasmid with a mercury detoxification operon $b l a_{\mathrm{KPC}-2}, b l a_{\mathrm{OXA}-9}$ and $b l a_{\mathrm{TEM}-1 \mathrm{~A}}$ genes from ST69 to ST131 [70]; and transfer of a range of sulphonamide- (sul2) and ampicillin-resistance genes $\left(b l a_{\text {TEM-1b }}\right)$ on a pNK29 plasmid within $E$. coli subtypes [71, 72]. Moreover, the frequency of conjugation was ten times higher and more stable in $b l a_{\text {СTX-M- }}$ ${ }_{15}$-producing ST131 than in K. pneumoniae [73].

This study focused on uropathogenic ST131 Clade C (fimH30) because of its high plasmid and AMR gene diversity [50, 61] where the mobile resistome and how plasmids mediate AMR gene composition needs deeper scrutiny. Here, we found a large shared core preterm infant resistome and a smaller accessory one that varied between closely related isolates. This was caused by plasmid turnover and rearrangements, affecting fimbrial genes too. We hypothesise that certain plasmids are more compatible with ST131 genomes, and applied topological data analysis (TDA) to understand plasmidchromosome co-evolution.

\section{RESULTS}

\section{A large core preterm infant resistome in E. coli}

We examined the preterm infant resistome and plasmid composition of seven E. coli ST131 genomes in the context of related reference genomes and non-pathogenic isolates. This resistome of 794 genes was assembled from 2004 contigs originally derived from DNA sequencing of 21 preterm infant faecal samples experimentally tested in vitro for resistance to 16 antibiotics (see Data Access, Table S1, available in the online version of this article) [1]. This resistome provided a cultureunbiased perspective on antibiotic resistance genes [1]. We found that seven ST131 Clade C genome assemblies from adult urinary tract infections (UTIs) together with subclade C2 reference genomes EC958 and NCTC13441 had 262 to 291 unique contigs in this resistome (Table 1). Commensal ST131 Clade A reference SE15 (O150:H5, fimH41) had 251 AMR contigs, and intestinal E. coli Human Microbiome Project (HMP) assembly 3_2_53FAA had 269. In contrast, well-studied asymptomatic urinary tract HMP sample 83972 
Table 1. E. coli genome assembly collection and metadata. The table shows the sample ID, SRA accession ID, ST131 Clade, bla ${ }_{\text {СTX-M }}$ allele(s), country and year of isolation, and numbers of unique AMR contigs in the preterm infant resistome. All seven ST131 assemblies, EC958 and NCTC13441 came from pathogenic UTIs. SE15 was a faecal commensal isolate. EC958 had 18 AMR contigs on plasmid pEC958A (pEC958B had none). NCTC13441 had 27 AMR contigs on its plasmid. The seven ST131 and two HMP samples were assembled from Illumina reads, and the three references were assembled from PacBio reads

\begin{tabular}{|c|c|c|c|c|c|}
\hline Sample ID & SRA ID & $\begin{array}{l}\text { ST131 } \\
\text { clade or } \\
\text { ST }\end{array}$ & $\begin{array}{l}b l a_{\text {Стх-м }} \\
\text { allele(s) }\end{array}$ & $\begin{array}{c}\text { Country, } \\
\text { year }\end{array}$ & $\begin{array}{c}\text { Unique } \\
\text { AMR } \\
\text { contigs }\end{array}$ \\
\hline 8289_1\#91 & ERR191724 & $\mathrm{C} 1$ & 14 & $\begin{array}{c}\text { Ireland, } \\
2007\end{array}$ & 268 \\
\hline 8289_1\#35 & ERR191668 & $\mathrm{C} 1$ & 14 & $\begin{array}{c}\text { Ireland, } \\
2008\end{array}$ & 270 \\
\hline 8289_1\#3 & ERR191636 & $\mathrm{C} 2$ & 15 & $\begin{array}{c}\text { Ireland, } \\
2005\end{array}$ & 274 \\
\hline 8289_1\#34 & ERR191667 & $\mathrm{C} 2$ & 15 & $\begin{array}{c}\text { Ireland, } \\
2010\end{array}$ & 274 \\
\hline 8289_1\#24 & ERR191657 & $\mathrm{C} 2$ & 14 and 15 & $\begin{array}{c}\text { Ireland, } \\
2009\end{array}$ & 283 \\
\hline 8289_1\#60 & ERR191693 & $\mathrm{C} 2$ & 15 & $\begin{array}{c}\text { Ireland, } \\
2010\end{array}$ & 262 \\
\hline 8289_1\#27 & ERR191660 & $\mathrm{C} 2$ & 15 & $\begin{array}{c}\text { Ireland, } \\
2010\end{array}$ & 262 \\
\hline SE15 & AP009378 & A & none & $\begin{array}{l}\text { Japan, } \\
2010\end{array}$ & 251 \\
\hline NCTC13441 & ERS530440 & $\mathrm{C} 2$ & 15 & UK, 2003 & 280 \\
\hline EC958 & HG941718 & $\mathrm{C} 2$ & 15 & UK, 2005 & 291 \\
\hline 3_2_53FAA & - & ST95 & none & $\begin{array}{c}\text { Canada, } \\
2007\end{array}$ & 269 \\
\hline 83972 & - & ST73 & none & $\begin{array}{c}\text { Sweden, } \\
1978\end{array}$ & 213 \\
\hline
\end{tabular}

from ST73 [74] had 213 unique contigs, suggesting a subset of AMR genes may be associated with symptomatic ST131 UTIs.

Comparing the AMR contigs' gene product functions identified a core resistome of 210 AMR contigs shared by all (Fig. 1), highlighting that these may be essential for non-pathogenic isolates. This core resistome differed from the accessory resistome of 109 contigs, of which 50 in ST131 Clade C alone corresponded to 18 unique AMR genes (Fig. 1). These accessory AMR genes were identified with ARIBA v2.11.1 [75] and the Comprehensive Antibiotic Resistance Database (CARD) [76], where matches were verified by read mapping to the reference resistome using GROOT [77].

\section{A diverse accessory preterm infant resistome among closely related ST131 isolates}

$B l a_{\mathrm{CMY}}$ encoding ESBL AmpC is typically associated with cephalosporin-resistance [78] and here nine variants (alleles CMY-37, 51, 66, 67, 85, 98, 101, 105) resolved from 17 AMR contig matches were unique to EC958 (Fig. 1). All Subclade C2 isolates bar 8289_1\#27 had five bla $a_{\text {TEM }}$ alleles (TEM-57, 104, $116,215,220)$ encoding an Ambler class A $\beta$-lactamase. The sole bla ${ }_{\text {СТХ-м-14- }}$ and bla ${ }_{\text {СTX-M-15 }}$-positive isolate (8289_1\#24) had unique four genes linked to aminoglycoside and tetracycline resistance (Table S2), a combination that may neutralise the effect of aminoglycoside susceptibility associated with tetracycline efflux pump TetA expression $[79,80]$.

Additional comparisons using the NCTC13441 genome showed that it had five $b l a_{\text {OXY }}$ alleles (OXY-1-1, 1-2, 2-3, 6-2, 6-4) encoding an Ambler class A ESBL (Text S1). Ten AMR contigs in all C2 corresponded to a single helix-turn-helix-like transcriptional regulator gene (Fig. 1). Two contigs present in all ST131 encoded $\operatorname{araC}$ (a transcriptional regulator) and $s u g E$ (associated with resistance to quaternary ammonium salts). The 39 AMR contigs in all bar 83972 included 28 copies of $m d f A$, encoding a multi-drug efflux pump linked to broadspectrum AMR [81]. The 3_2_53FAA and 83972 shared ftsI encoding a transpeptidase catalysing peptidoglycan crosslinking [82] with the synonym penicillin-binding protein 3 (PBP3) [83, 84], and is sensitive to ESBLs [85].

For a wider context on ST131 dynamics, comparing this preterm infant resistome with Klebsiella pneumoniae showed that an interspecies shared resistome had 58 genes and that the larger K. pneumoniae core resistome of 308 genes included $b l a_{\mathrm{SHV}}$. Nine of ten genes in pathogenic K. pneumoniae isolate PMK1 that were absent from a urinary tract microbiome assembly (WGLW1) were $b l a_{\text {OXY }}$, NCTC13441. Repeating this with the more divergent Staphylococcus aureus and lugdunensis found 14 shared AMR genes on S. aureus plasmids only.

\section{Extensive plasmid rearrangements in closely related ST131 Clade C genomes}

To evaluate the origin and relationships of the AMR genes in these seven Clade $\mathrm{C}$ (Table 1), we initially found with PlasmidFinder [86] that all had IncF1A and some C2 had lost IncF1B, suggesting potential plasmid changes (Table S3). We aligned these seven assemblies to plasmids common in ST131 (pEK499, pEK516, pEK204, pCA14, pV130) and repeated this via read mapping. Plasmids pEK499 (from England), pEK516 (England) and pEK204 (Belfast) were geographically near these ST131 (all from Ireland). SE15's pECSF1 122.3 Kb IncF2A/F1B plasmid was used as a control because it had no known AMR genes [87]. The 8289_1\#35 and 8289_1\#91 (both from C1) had identical results, and vice versa for 8289_1\#60 and 8289_1\#27 (both from C2) and so are not discussed below.

Clade C ST131 had more similarity to IncF2/F1A bla ${ }_{\text {CTX-M- }}$ ${ }_{15}$-positive plasmid pEK499 than SE15 and the two HMP samples, but to varying degrees (Fig. 2). This plasmid has 185 genes, lacks traX for conjugation, is stably inherited (Table S4), and may have been gained early in the origins of Clade $\mathrm{C}$ as a fusion of type F2 and F1A replicons [88]. Nine of pEK499's ten key AMR genes are in a $25 \mathrm{~Kb}$ segment spanning bla ${ }_{\text {TEM' }}$ $b l a_{\mathrm{OXA}-1}$ and $b l a_{\mathrm{CTX}-\mathrm{M}-15}$ at 40,58 and $63 \mathrm{~Kb}$ (respectively). The 8289_1\#3 and 8289_1\#24 (both C2) had all three, 8289_1\#27, 8289_1\#60 and 8289_1\#34 (all C2) had bla ${ }_{\mathrm{OXA}-1}$ and bla $a_{\mathrm{CTX}-\mathrm{M}-15}$ 


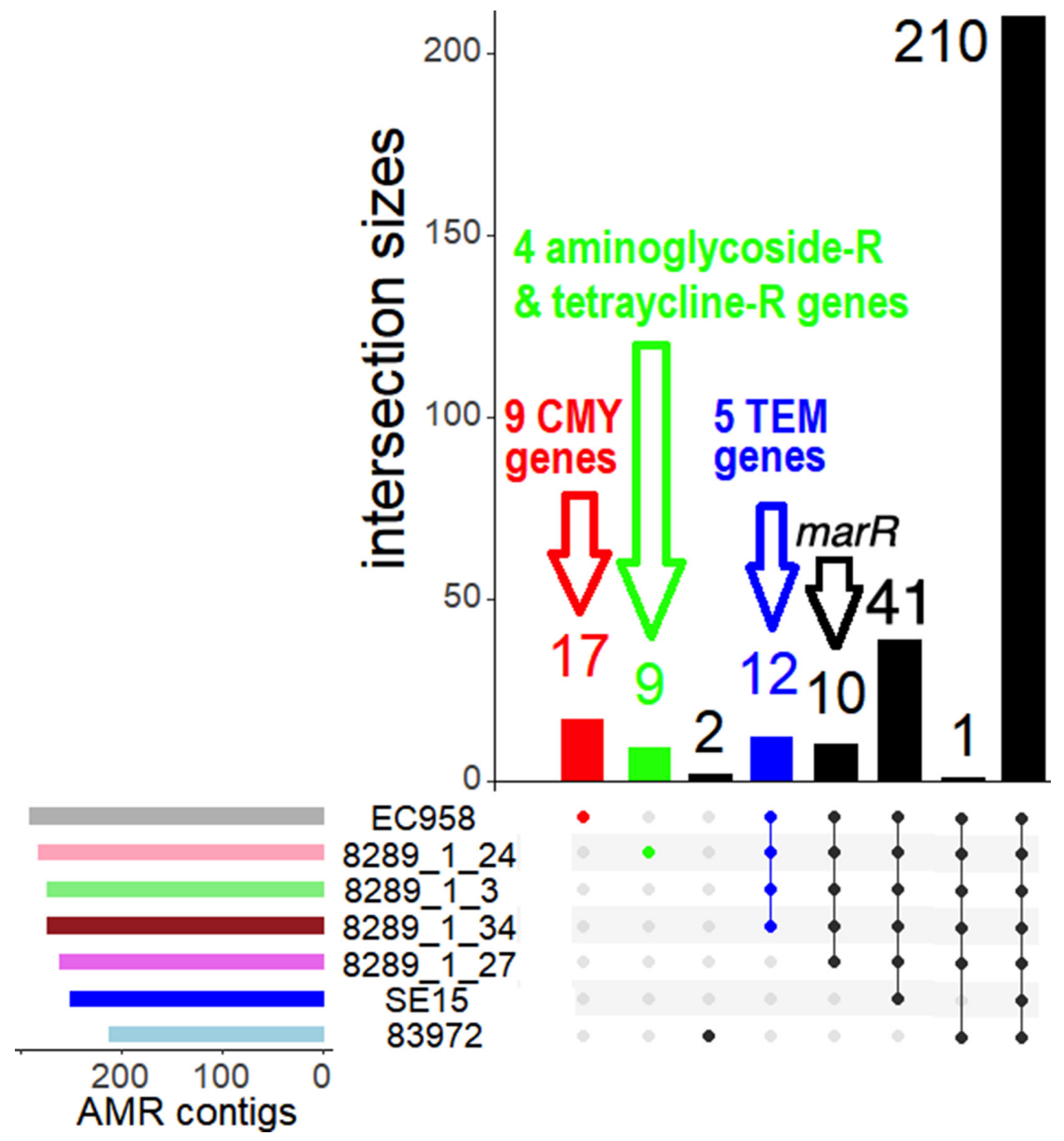

Fig. 1. The overlap of preterm infant AMR contigs across four ST131 subclade C2 assemblies (8289_1\#3, 8289_1\#24, 8289_1\#27. 8289_1\#34), two ST131 reference genomes (EC958 and SE15) and two HMP assemblies (83972 and 3_2_53FAA). Top: The intersection sizes (y-axis) and the numbers of AMR contigs per set showed that most (210) AMR contigs were shared across all isolates. The nonunique AMR contigs indicated smaller numbers of unique AMR genes, so EC958's 17 AMR contigs (red) corresponded to nine unique bla ${ }_{\text {сMY }}$ genes (Table S2); and 8289_1\#24's nine contigs (green) represented four aminoglycoside and tetracycline resistance genes (Table S3). All Clade C bar 8289_1\#27 had 12 contigs (blue) denoting to five bla $a_{\text {TEM }}$ genes (Table S4). Bottom: The numbers of AMR contigs per sample with the corresponding sets (coloured circles).

but not $b l a_{\text {TEM }}$, whereas C1 (8289_1\#35 and 8289_1\#91) were $b l a_{\text {TEM }}$ - and $b l a_{\text {СТХ-м-14 }}$-positive. Conjugation (tra) genes were in all ST131 except 8289_1\#34. IncF2A plasmid pEK516 has $\sim 75 \%$ similarity to pEK499 but is shorter (64.6 Kb) [59] and is usually non-conjugative [89]. This plasmid has 103 genes including $b l a_{\mathrm{TEM}}, b l a_{\mathrm{OXA}-1}$ and $b l a_{\mathrm{CTX}-\mathrm{M}-15}$, and a type I partitioning locus for stable inheritance absent in pEK499 (Table S4). Read mapping to pEK516 showed that Clade $\mathrm{C}$ had high similarity to it, unlike SE15 and the HMP samples (Fig. S1).

Contrasting sharply with pEK499 and pEK516, 8289_1\#27 (C2) reads mapped to conjugative IncI1 plasmid pEK204 found $72.8 \mathrm{~Kb}$ regions of similarity, unlike the others that had $<10 \mathrm{~Kb}$ (Fig. 2). PEK204 is similar to IncI1 plasmid R64, has 112 genes, a complete tra region (Table S4), and a type I partitioning locus [59]. 8289_1\#27 had a complete I1 replicon, oriT, tra, shufflons subject to site-specific recombinase activity, and a pil cluster encoding a type IV fimbriae associated with enhanced cell adherence and biofilm formation in entero-aggregative and Shiga toxin-producing E. coli [90]. A $9.3 \mathrm{~Kb}$ region on pEK204 contained bla $a_{\text {TEM-1b }}$, inactive transposase Tn3-tnpA, ISEcp1, bla $a_{\text {СтX-M }}$ and a 5' orf477-tnpAtnpR region. The $14 \mathrm{bp} \mathrm{IRL} \mathrm{5'} \mathrm{of} \mathrm{ISEcp} 1$ and IRR at the distal end of the inverted orf 477 element can mobilise $b l a_{\text {CTX-M, }}$ and an additional IRR at impB $3^{\prime}$ of the $b l a_{\text {TEM-1b }}$ gene $(7.4 \mathrm{~Kb}$ further away) can mobilise the $9.3 \mathrm{~Kb}$ unit [91], which has been found on IncFIA, IncFIA-FIB, IncN and IncY plasmids after originating on a pCOL1b-P9-like plasmid [59]. $\operatorname{Imp} B$ and impA encode an error-prone DNA repair protein (like UmuDC) [92]. 

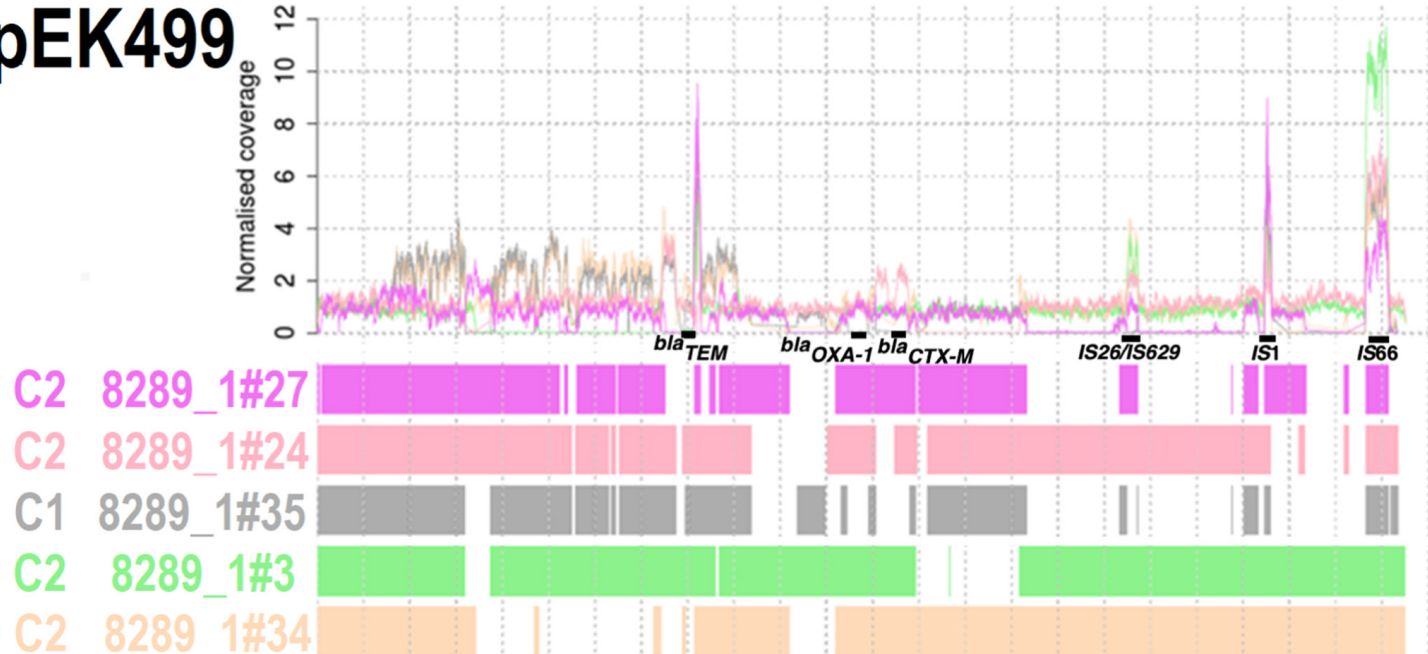

A SE15
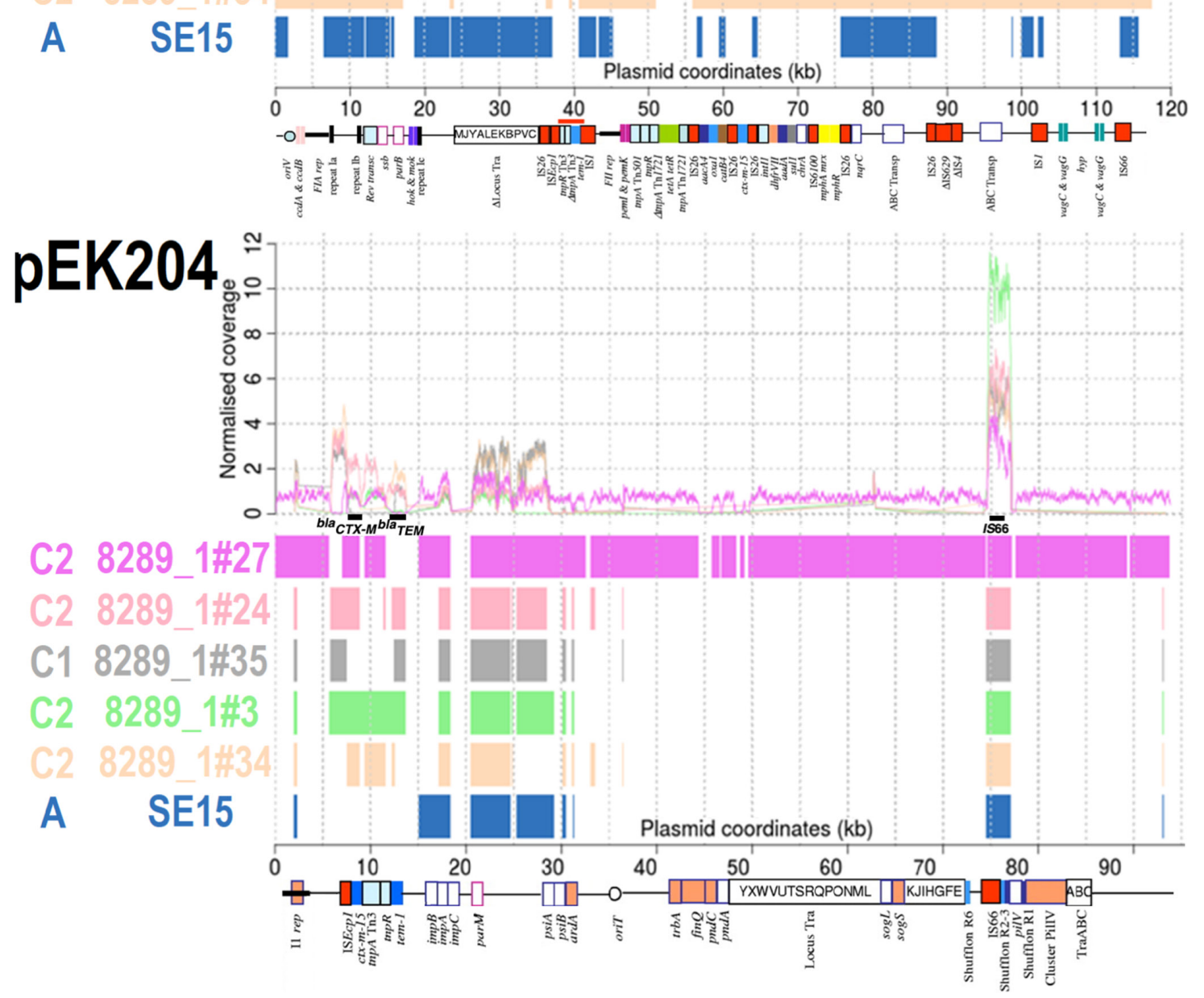

Fig. 2. Comparison of pEK499 (top, 117536 bp) and pEK204 (bottom, 93732 bp) with five ST131 C1 and C2 isolates, ST131 Clade A reference SE15 (navy) and two HMP assemblies (3_2_53FAA in dark green and 83972 in cyan). Top: Normalised read coverage showed high copy numbers of IS1 (at 41 and $103 \mathrm{~Kb}$ of pEK499) and IS66 (at 75-77 Kb of pEK204, and at $113 \mathrm{~Kb}$ of pEK499). Bottom: BLAST alignments showed limited similarity for the HMP assemblies and SE15 relative to higher levels for Clade C for pEK499:8289_1\#27 (C2, mauve), 8289_1\#24 (C2, pink), 8289_1\#35 (C1, grey), 8289_1\#3 (C2, light green), 8289_1\#34 (C2, beige). For pEK204, only 8289_1\#27 had many regions of similarity. Genes encoding bla $a_{\text {TEM' }}$ bla $a_{\text {OXA-1 }}$ and bla $a_{\text {CTX-M-15 }}$ are at 40, 58 and $63 \mathrm{~Kb}$ on pEK499 (respectively). The bla CTX-M $_{\text {. }}$ gene was at $8 \mathrm{~Kb}, b \mathrm{a}_{\mathrm{TEM}}$ was at $13 \mathrm{~Kb}$, followed by mixed conjugation and segregation genes at 36-70 Kb on pEK204. For pEK204, the bla $a_{\text {CTX-M-3 }}$ gene differs from bla $a_{\text {CTX-M-15 }}$ by a single R240G substitution, and so bla $a_{\text {CTX-M }}$ genes detected here were bla $a_{\text {CTX-M-15. The annotation }}$ was modified from [59]. Matches spanning $>300$ bp are shown. 
Table 2. The numbers of protein-coding genes per plasmid, unique genes per plasmid, length, and numbers of non-redundant PPIs within the plasmid and with the chromosome, and the rate of indirect interactions (non-trivial loops) per PPI. Plasmid pEK516 had the same results as pEK499

\begin{tabular}{|c|c|c|c|c|c|c|}
\hline \multirow[t]{2}{*}{ Plasmid } & \multirow[t]{2}{*}{ No. of genes } & \multirow[t]{2}{*}{ No. of unique genes } & \multirow[t]{2}{*}{ Length (Kb) } & \multicolumn{2}{|c|}{ No. of unique PPIs } & \multirow[t]{2}{*}{ Non-trivial loops per PPI } \\
\hline & & & & Within plasmid & With chromosome & \\
\hline pEK204 & 112 & 87 & 93.7 & 21 & 548 & 0.096 \\
\hline pEK499 & 185 & 87 & 117.5 & 8 & 758 & 0.117 \\
\hline pEK516 & 103 & 55 & 64.6 & 8 & 758 & 0.117 \\
\hline pJIE186-2 & 138 & 78 & 137.7 & 2 & 32 & 0.015 \\
\hline pCA14 & 181 & 93 & 155.4 & 5 & 0 & 0 \\
\hline pEC958A & 142 & 75 & 135.6 & 5 & 0 & 0 \\
\hline pECSF1 & 150 & 70 & 122.3 & 0 & 0 & 0 \\
\hline
\end{tabular}

Further investigation of the ST131 plasmid-matching regions showed variable plasmid similarity within closely related isolates. Read mapping to conjugative plasmid pCA14 showed that all Clade C bar 8289_1\#3 had Mrx and mph(A) genes associated with macrolide resistance (Fig. S3). This was also found by comparing with contigs from non-conjugative plasmids pV130a and pV130b from sewage treatment plant water in India [93], where 8289_1\#27 and 8289_1\#60 (both C2) had similarity spanning all the pV130a contigs (Fig. S2).

\section{High rates of pEK499 and pEK204 protein-protein interactions with chromosomal $E$. coli Proteins}

The extensive diversity of Clade C AMR genes and plasmids raised the question of how the plasmids' gene products interact with chromosomal ones. Protein-protein interaction (PPI) networks can examine plasmid-chromosome coevolution based on gene products' topological proximity [94, 95], which could be higher for plasmid and chromosomal proteins that have co-existed and so may interact more [96]. We used topological data analysis (TDA) to measure the number of non-trivial (indirect) loops where a loop is a chain of at least four PPIs ending at the same protein where it started. We focus on a type of loops called 'non-trivial' (see Methods). The number of non-trivial loops was scaled by the number of PPIs per dataset (Table 2).

PPI data for 4146 E. coli protein-coding genes with 105457 PPIs (all combined scores $>400$ ) from the Search Tool for the Retrieval of Interacting Genes/Proteins (STRING) database v10 [97] was used to get the numbers of non-redundant PPIs and loops per PPI for a plasmid among its own proteins, and then between the plasmid's proteins and the 4146 chromosomal proteins. We assessed the numbers of PPIs from a combined score threshold of 400 to 900 with a step size of 25 . We tested our approach using a published E. coli clustering of 60 genes [98] that had a rate of 0.244 non-trivial loops per PPI, which was lower than the rate of 0.518 obtained for the 4146 chromosomal proteins (Table S5, Fig. S4). There were lower rates of non-trivial loops per PPI for pEK499 (0.117) and pEK204 (0.096), but the plasmids' rates were almost constant across the combined score thresholds (Fig. S5). This held even though the number of PPIs per protein was negatively correlated with the combined score (Fig. S6), suggesting that the rate of non-trivial loops per PPI was robust to changes in the combined score threshold. We found that pEK499 and pEK204 interacted with chromosomally encoded proteins, but pCA14, pEC958A and pECSF1 did not (Table S6), and pJIE186-2 had a small number of PPIs (Table 2) that may be VFs [99].

\section{ST131 genomes had an ancestral pEK499-like plasmid but some gained a pEK204-like one}

The seven ST131 assemblies above were from a set of 4071 ST131 from Clades A, B and C [61] that were aligned here to pEK499 and pEK204 with BLAST. Of these 837 (20.6\%) had $>10 \mathrm{~Kb}$ of regions similar to pEK204 (Fig. S7), whereas 3108 (76.3\%) had $>10 \mathrm{~Kb}$ like pEK499 (Fig. S8). All 193 assemblies with $>40 \mathrm{~Kb}$ of pEK204-like segments were from Clade C: 17 from C0 (out of 52, 33\%), 82 from C1 (out of 1119, 7\%) and 94 from C2 (out of 2051, 5\%) (Fig. 3). All 17 from C0 had an I1 replicon, bla ${ }_{\text {СтХ-М }}$ gene, $b l a_{\text {TEM }}$ gene (bar one isolate) and at least a partial tra region, and 13 had the pil operon (76\%). The 82 from $\mathrm{C} 1$ and 94 from C2 had lower rates of I1 replicon presence (C1 77, C2 81\%), partial tra regions (C1 94, C2 $86 \%$ ) and pil clusters (C1 $n=60$ or $73 \%, \mathrm{C} 2 n=71$ or $76 \%$ ) but differed in the rates of gene presence for $b l a_{\text {CTX-M }}(\mathrm{C} 128$ $\%$ vs C2 $83 \%$, odds ratio $=12.5,95 \%$ CI $6.1-25.8, P=\mathrm{e}-11)$ and $b l a_{\text {TEM }}$ (C1 59\% vs C2 30\%, odds ratio=3.3, 95\% CI 1.8-6.2, $P=2.2 \mathrm{e}-5)$. This implied $b l a_{\text {Стх-м }}$ (via orf477) was common in $\mathrm{C} 2$ and $b l a_{\mathrm{TEM}}($ via $i m p B)$ in $\mathrm{C} 1$ due to different ancestral transposition of the $9.3 \mathrm{~Kb}$ region.

To resolve the origin of pEK204-related pil HGT, we searched for the 14 pil operon genes (pilIJKMNOPQRSTUVI) individually in the 4071 assemblies [61]. The entire pil operon was conserved in 376 (9\%), including 61 from A (out of 414, 15\%), 97 from B (out of 433, 22\%), 17 from C0 (out of 52, 33\%), 95 from C1 (out of 1,121, 8.5\%) and 106 from C2 (out of 2051, $5.2 \%$ ) (Table 3) (see Data Access). Linked with the pEK204 matches, this indicated potential non-pEK204 pil ancestral acquisition in Clades $\mathrm{A}$ and $\mathrm{B}$, and the putative Clade C 

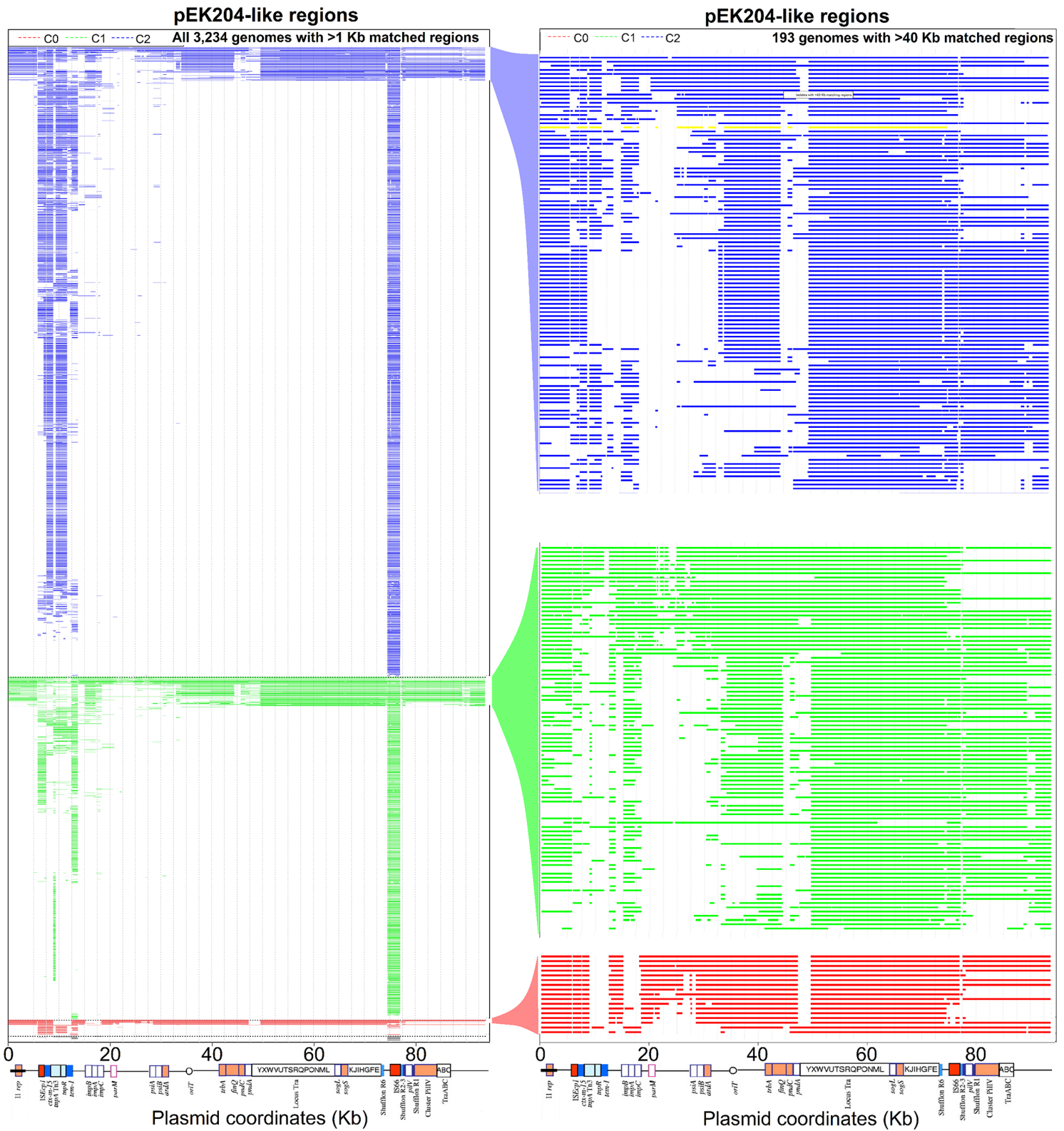

Fig. 3. The distributions of pEK204-like regions in ST131 Clade C genome assemblies with $>1 \mathrm{~Kb}$ (left, $n=3234$ ) and $>40 \mathrm{~Kb}$ (right, $n=193$ ) of matching segments. The regions of similarity were examined in (left) Subclades B0 ( $n=14$ in black), C0 ( $n=51$ in red), C1 ( $n=1119$ in green) and C2 ( $n=2051$ in blue), and (right) C0 ( $n=17$ in red), C1 ( $n=82$ in green) and C2 ( $n=94$ in blue). The $8289 \_1 \# 27$ (c2) is highlighted in yellow. Similarity across pEK204 (93732 bp) was based on BLAST alignment. The bla $a_{\text {CTX-M }}$ gene was at $8 \mathrm{~Kb}$, bla $\mathrm{T}_{\text {TEM }}$ was at $13 \mathrm{~Kb}$, followed by a mix of conjugation and segregation genes at 36-70 Kb. This suggested independent integrations and rearrangements of pEK204like plasmids across the subclades. The annotation was modified from [59].

ancestor may have had a pEK204-like plasmid with no pil that subsequently gained by recombination in some isolates.

We extended this to two other important fimbrial operons: pap (pyelonephritis-associated pili) and $u c l$ (uroepithelial cell adhesin-like). All four $u c l$ genes ( $u c l A B C D)$ were in $17.5 \%$ (712) of isolates, including 21 from A (5\%), 30 from B (7\%), 25 from C0 (48\%), 94 from C1 (8\%) and 542 from C2 (26\%) (Table 3). All ucl-positive C2 genomes (bar one sample) had a complete pap operon. The pap operon was in a minority
$(26 \%, 1049)$ of isolates, including 28 from A ( $7 \%), 163$ from B (38\%), 49 from C0 (94\%), 127 from C1 (11\%) and 682 from C2 (33\%) (Table 3). Most isolates had papIBA but not the genes $3^{\prime}$ of them (papHCDJKEF) $(65 \%, n=2661): 359$ from A (87\%), 118 from B (27\%), 3 from C0 (6\%), 888 from C1 (79\%) and 1293 from C2 (63\%). PapI (234 bp) is associated with higher P fimbriae expression in E. coli CFT073 [100] and here was amplified to two, three or four copies in $22 \%$ ST131 : 26 in Clade A (6\%), 51 in B (12\%), 45 in C0 (87\%), 119 in 
Table 3. Fim, pil, pap and ucl operon genes detected in 4071 ST131 genome assembles. The numbers and percentages of isolates per subclade with complete or absent (-) pil (pilK-pilV) or pap or $u$ cl (uclABCD) operon genes where a subset also had three pap genes (paplBA). This focused on isolates allocated to the eleven main allelic options, isolates with some level of partial operon presence or absence were too sparse to be informative. UclBCD but not uclA was in an additional $2 \%(n=77)$, including seven from A (2\%), 28 from B (6\%), none from C0, 24 from C1 (2\%), and 18 from C2 (1\%)

\begin{tabular}{|c|c|c|c|c|c|c|c|c|c|c|c|c|c|}
\hline \multicolumn{3}{|c|}{ Operon } & \multicolumn{11}{|c|}{ Subclade } \\
\hline- & papIBA & - & 279 & $67 \%$ & 107 & $25 \%$ & 3 & $6 \%$ & 772 & $69 \%$ & 1192 & $58 \%$ & 2353 \\
\hline- & all & all & 21 & $5 \%$ & 13 & $3 \%$ & 23 & $44 \%$ & 82 & $7 \%$ & 481 & $24 \%$ & 620 \\
\hline all & papIBA & - & 57 & $14 \%$ & 2 & $<1 \%$ & & & 75 & $7 \%$ & 66 & $3 \%$ & 200 \\
\hline all & - & - & 3 & $<1 \%$ & 71 & $16 \%$ & & & 5 & $<1 \%$ & 3 & $<1 \%$ & 82 \\
\hline all & all & all & & & 16 & $4 \%$ & 1 & $2 \%$ & 10 & $<1 \%$ & 33 & $2 \%$ & 60 \\
\hline all & all & - & 1 & $<1 \%$ & 6 & $1 \%$ & 16 & $31 \%$ & & & 4 & $<1 \%$ & 27 \\
\hline all & - & all & & & & & & & 1 & $<1 \%$ & & & 1 \\
\hline - & - & all & & & & & & & & & & & 0 \\
\hline \multicolumn{3}{|c|}{ Partial matches } & 52 & $13 \%$ & 124 & $29 \%$ & 9 & $17 \%$ & 168 & $15 \%$ & 257 & $13 \%$ & 610 \\
\hline \multicolumn{3}{|c|}{ Totals } & 414 & & 433 & & 52 & & 1121 & & 2051 & & 4071 \\
\hline
\end{tabular}

C1 (11\%) and 658 in C2 (32\%). Only 45 assemblies had an amplified $p a p B$, and 265 had an amplified papA. These two genes $(p a p B A)$ share a promoter $p B A$, and $p a p I$ has a separate one $(p I)$.

Most isolates from A, C1 and C2 and a minority of B had no pil nor $u c l$ operons and lost the papH-F segment (Table 3). Clade B differed from A because some from this diverse clade have either pil or pap, but not both. The 83 ST131 with no detected pap genes all had a pil operon, and most (71 of 83) were from Clade B. Given the fim operon's key role in ST131 evolution, we verified that fim was intact in $>99 \%$ of the 4071 . As expected, the ISEc55 insertion at $\operatorname{fimB}$ [101] that delays fim expression in Clade C (like EC958 [20]) was in $>99 \%$ of C1 $(1117,99.6 \%)$ and C2 $(2041,99.5 \%)$, but rarer in A $(236,57 \%), \mathrm{B}(93,21 \%)$ and C0 $(18,35 \%)(32$ samples had additional fimB rearrangements). During the period prior to the divergence of $\mathrm{C} 0$ from $\mathrm{C} 1$ and $\mathrm{C} 2$ [50], the Clade $\mathrm{C}$ ancestor likely had a complete pap operon (but not pil nor $u c l$ ). The $\mathrm{C} 1 / \mathrm{C} 2$ ancestor gained the fimB ISEc55 insertion and a minority of $\mathrm{C} 1$ gained either pil (80,7\%) or ucl $(82,7 \%)$ or both $(11,1 \%)$, whereas $24 \%$ of $\mathrm{C} 2$ gained $u c l$ (482), 4\% pil alone (73) and 2\% both ucl and pil (33).

Unlike $u c l$ gene products that are functionally independent [102], regulatory protein PapB reduces fim operon expression by inhibiting FimB and activating FimE, both tyrosine site-specific recombinases that invert fimS, including in $E$. coli CFT073 and 536 [103-105]. PapI and PapB regulate pap expression [104-106] depending on their concentrations and protein binding at the $416 \mathrm{bp}$ regulatory region between $p a p I$ and $p a p B$. Thus, retention of papIBA in $>65 \%$ of ST131 could be linked to fim transcriptional regulation by PapB. Using the STRING PPI network data above for CFT073 and 536 that have fim, pap and $u c l[107,108]$ (no pil gene products were found), there were ten fim-pap inter-operon PPIs in both 536 and CFT073, including pilus rod subunit PapA with FimD and FimF (as well as FimC), potentially matching the PPIs of FimA [109]. If only papIBA was present, the functional effects (if any) of papI and papA remain uncertain because it is unclear if FimC (replacing PapD at the inner cell membrane) could mediate periplasmic transport of PapA (like FimA) subunits via the chaperone FimI (instead of $\mathrm{PapH}$ ) to usher FimD (rather than PapC) for pilus rod assembly at the outer cell membrane, extended later by FimF (in lieu of PapK) for the base of the tip. Nonetheless, presence of these genes can inform pilicide and coilicide design, such as antibodies targeting VF PapA [109].

\section{DISCUSSION}

Commensal and environmental bacteria are major reservoirs of AMR genes [110], which are driven by HGT and recombination events [111], including in E. coli [112-115] and microbiome species $[116,117]$. Previous work screened contigs from preterm infants for resistance to 16 antibiotics [1]. Here, we showed that this resistome was shared extensively between ExPEC ST131, commensal ST131 and microbiome E. coli, indicating likely transfer of these genes across commensal and pathogenic bacteria inhabiting the human gut and urinary tract, as expected [118]. 
E. coli 83972 does not express functional fimbrial adhesins and is used for therapeutic urinary bladder colonisation in patients in which it protects against super-infection [119-121]. Although 83972 lost virulence during its adaptation to commensalism [122], here it had AMR genes like PBP3 that it shared with an E. coli gut microbiome (3_2_53FAA). This retention of certain AMR genes in asymptomatic specimens is important when assessing the AMR gene evolution in ST131 [123, 124].

Within ST131, Clade C core genomes are highly conserved but accessory genomes have extensive differences in AMR gene content $[50,52,61]$. Here, this was supported by NCTC13441's repertoire of $b l a_{\mathrm{TEM}}$ and $b l a_{\mathrm{OXY}}$ genes, contrasting with EC958's variety of bla $a_{\mathrm{CMY}}$ ones. This reinforced the view that ST131's accessory resistome is shaped by the environment mediated by plasmids, rather than population structure or geographic factors [125], so perhaps tracking plasmids and MGEs in addition to AMR genes [42, 126] could assist treatment diagnostics [127].

By combining seven Clade $\mathrm{C}$ genome assemblies, then these with 4064 Clade $\mathrm{C}$ assemblies, we found that most (78\%) ST131 had $>10 \mathrm{~Kb}$ of regions similar to plasmid pEK499 and some (9\%) had regions with high similarity to IncI1 plasmid pEK204, suggesting either discrete gains of pEK204-like plasmids in each $\mathrm{C}$ subclade or its presence in the Clade $\mathrm{C}$ ancestral lineage. IncI1 plasmids are common in ExPEC and are associated with different ESBL genes [67, 128-130]. Given that backbone plasmid genes may determine fitness effects more than ESBL genes [131] and long-term IncF plasmid persistence in ST131 [62], plasmids pEK204, (pEK516,) and pEK499 proteins' higher interaction rates with chromosomally-encoded proteins relative to other relevant plasmids could be due to co-evolution. Measuring the indirect connectivity as PPI network loops per interaction showed evidence of this long-term retention, and may help identify plasmids compatible with E. coli chromosomes.

ST131's fitness advantage is tightly correlated with type 1 fimbriae variant fimH30 and delayed fim operon expression due to an insertion at fimB $[17,132,133]$. Here, a minority of ST131 had type IV pilus biosynthesis (pil) genes and most Clade C with pil had $>40 \mathrm{~Kb}$ of regions similar to pEK204, whereas Clade A and B isolates with pil did not have pEK204like regions. Pil may allow different epithelial cell adhesion from fim via a thinner pilus and biofilm formation [90]. Additionally, F17-like ucl operon was more common in C2 (24\%): UclD (like FimH) is a two-domain tip adhesin that binds intestinal epithelial cells via O-glycans (FimH uses $\mathrm{N}$-glycans) [102]. The $u c l$ operon is associated with uroepithelial cell adhesion, biofilm formation and could be mobilised by its flanking MGEs [134].

The pap operon encodes a P fimbriae with high specificity for kidney epithelial cell and erythrocyte receptor glycolipids ( $\alpha$-D-galactopyranosol(1-4)- $\alpha$-D-galactopyranoside) [135]. Delayed fim expression in Clade C $[20,101]$ may be reduced further by PapB: papIBA alone was retained in $>65 \%$ of Clade $\mathrm{C}$ here. Delayed fim expression [136] and having multiple $\mathrm{P}$ fimbrial gene clusters [106] associates more with pyleonephritis than cystitis. Given that $E$. coli express single fimbriae at the cell surface $[103,137]$ and isogenic cell populations can express distinct fimbrial types [138], type 1 fimbriae may allow bladder colonisation followed by reduced expression in favour of P fimbriae when at the kidney [137]. Our results on plasmid-linked changes across the ST131 resistome and diversity of fimbrial gene composition could inform on potential infection mechanisms [139] and biofilm formation [20].

\section{METHODS}

\section{E. coli genome isolate collection}

Of the 12 E. coli assemblies examined (Table 1), three were ST131 references: SE15, NCTC13441 and EC958. Seven were ST131 from Ireland in 2005-2010, of which two from C1 were $b l a_{\text {CTX-M-14 }}$-positive, as was 8289_1\#24 from C2, and all five from C2 were $b l a_{\text {CTX-M-15 }}$-positive. All seven were from urine except 8289_1\#34, which was a rectal swab. The two HMP samples were: 3_2_53FAA (aka EC3_2_53FAA) from a 52-year-old male Canadian with Crohn's disease's colon biopsy [140]. The 83972 (aka EC83972) sample was from the urine of a Swedish girl with a 3 year history of asymptomatic bacteriuria and stable renal function [141]. The 83972's have common ancestry with virulent pyelonephritiscausing ExPEC CFT073 [142]. ST131 C2 reference genomes NCTC13441 and EC958 were from UTIs in the UK, and had bla $a_{\text {CTX-M-15 }}$-positive plasmids $[10,59,132]$. NCTC13441 has 4983 predicted protein-coding genes and EC958 has 4982. EC958 has numerous virulence-associated genes that encode adhesins, autotransporter proteins and siderophore receptors, and can cause impairment of uterine contractility in mice [143]. Plasmid pEC958A has $85 \%$ similarity with pEK499 but lacks the latter's second tra region due to an IS26-mediated $b l a_{\text {TEM-1 }}$ insertion $[10,60,132]$. ST131 Clade A reference SE15 was examined as a genetic outgroup and a commensal control because it lacks many virulence-associated genes. It has a 4717338 bp chromosome with 4338 protein-coding genes and a $122 \mathrm{~Kb}$ plasmid pSE15 with 150 protein-coding genes [87].

\section{Illumina library quality control and read mapping}

The paired-end Illumina HiSeq libraries for each sample were screened for low quality (Phred score $<30)$ and short $(<50 \mathrm{bp})$ reads using Trimmomatic v0.36 [144] and corrected using BayesHammer from SPAdes v3.9 [144] (Table S7). These corrected read libraries were mapped to references with SMALT v7.6 (www.sanger.ac.uk/resources/software/smalt/), and the SAM files were converted to BAM format, sorted and PCR duplicates removed using SAMtools v1.19 [145].

\section{Homology-based resistome screening and comparison}

The read mapping to the reference resistome (Table S1, see Methods of [1]) used GROOT [77] where the reads were indexed using the median read length (Table S7). Contig and protein domain annotation was derived from the Pfam v27.0 and ProSite databases using InterProScan v5.22-61 
[146]. The protein homolog dataset in the CARD (2239 genes) [76] was aligned with the genomes to annotate the resistomes with BLAST v2.2.31, where matches with a bit score $>500$ and $>99 \%$ homology were considered valid. Alignments were visualised using Artemis and the Artemis Comparison Tool (ACT) [147], and also R packages VennDiagram v1.6.1, Seqinr v3.4-5, UpSetR v1.4.0 and WriteXLS v5.0.0.

\section{Assessment of plasmids prevalent in ST131}

Sequence and annotation files for pEK499 (NC_013122.1, EU935739), pEK516 (NC_013121.1, EU935738), pEK204 (NC_013120.1, EU935740) and all pV130 contigs (LC056314.1 to LC056328.1) [93] were aligned with Clustal Omega v1.2.1 [148]. Replicon typing used PlasmidFinder [56] and each plasmid was compared to the CARD. Each read library was mapped to each plasmid to verify local genetic features and quantify copy number levels, visualised with Artemis and $\mathrm{R}$ v3.4.2's Reshape2 v1.4.3, Ggridges v0.5.1, Ggplot2 v2.3.2.1, Readr v1.3.1, Dplyr v0.8.3 and Ape v5.3 packages. Sequence similarity was calculated using the Sequence Identity and Similarity (SIAS) tool (http://imed.med.ucm.es/Tools/sias. html). Homology searches against pEK204 and pEK499 in the 4071 genomes [60] examined matches $>300$ bp length with $>98 \%$ sequence identity.

\section{Protein-protein interaction network construction and topological data analysis}

TDA has been used to investigate complex and highdimensional datasets, like breast cancer genomes [149]. We applied it to PPI networks with a focus on direct and indirect connectivity across different network topologies by quantifying rates of absent PPIs (non-trivial loops). The numbers of non-trivial loops per PPI was used as a metric for indirect connectivity because it was consistent across parameters and was independent of network size. We assessed pCA14, pEK204, pEK499, pEK516 and pEC958A, along with two plasmids with no known AMR genes as negative controls: pECSF1 and pJIE186-2 [99]. We examined unique genes with PPI network information only. Results for pEK516 were identical to those for pEK499.

We extracted E. coli K12 MG1655 PPI data from the STRING database v10 [97] with R v3.5.2 packages BiocManager v1.30.4, Dplyr v0.8.0.1, Genbankr v1.10.0, Rentrez v1.2.1, STRINGdb v1.22.0, tidyverse v1.2.1 and VennDiagram v1.6.20. STRING's combined scores were used because they integrate multiple types of evidence while controlling for random PPIs [97]. Using a score threshold of 400, K12 had 4146 protein-coding genes, of which 4121 had interactions, resulting in 105457 PPIs - 14555 PPIs were present for a score threshold of 900. For each plasmid or set of genes, we obtained the unique genes and numbers of pairwise PPIs within that set and with the chromosome. We tested our TDA-based approach using previous work [98]. For E. coli 536, FooB was used as an equivalent for PapB, and likewise for F7-2 that matched VF PapA in CFT073, and FooG for PapG.
We constructed the Vietoris-Rips complex [150] where the proteins were the vertices with PPIs as edges, so that proteins A and B with a PPI would be joined by a single edge (two proteins in one dimension, 1-D). Proteins A, B and $C$ joined by three PPIs would have a filled 2-D triangle. For four proteins $\mathrm{A}, \mathrm{B}, \mathrm{C}$ and $\mathrm{D}$ joined by all six possible pairwise PPIs, their four filled 2-D triangles $A / B / C, B / C / D$, $\mathrm{A} / \mathrm{C} / \mathrm{D}$ and $\mathrm{A} / \mathrm{B} / \mathrm{D}$ constitute a tetrahedral surface filled with a 3-D tetrahedron. This can be extended to $m+1$ pairwise connected proteins, which get a $m-D$ polytope filled into their skeleton of edges, triangles, tetrahedra, and so on. For $m \geq 4$, a loop connects $m$ proteins by $m$ PPIs, such that each protein is involved in precisely two of these PPIs. For instance, four proteins $A, B, C, D$ can be joined to a loop by four PPIs A-B, B-C, C-D, D-A, where A-B is a PPI between the proteins $A$ and $B$ (etc). Any loop that can be filled with triangles, along existing PPIs, is called trivial. So if there is an interaction between $\mathrm{A}$ and $\mathrm{C}$, the loop is filled by the two triangles $\mathrm{AB}-\mathrm{BC}-\mathrm{CA}$ and $\mathrm{CD}-\mathrm{DA}-\mathrm{CA}$ and hence trivial. If there are no interactions between $A$ and $C$, and none between $\mathrm{B}$ and $\mathrm{D}$, then the loop is non-trivial.

Specialised software [151] was used to optimise the Betti number computations instead of using general purpose implementations of the Vietoris-Rips complex (such as SAGE) due to the large K12 dataset size (4146 proteins with 105457 interactions). This software used the sparsity of the boundary matrices to process the rank computations efficiently in LinBox [152], with a hard-coded dimensional truncation of the Vietoris-Rips complex to avoid the large number of high-dimension simplices that would be obtained for the full dataset. For each analysis across STRING combined scores 400 to 900 with a step of 25 , we computed the first Betti number of the Vietoris-Rips complex that counted the numbers of non-trivial loops (with missing PPIs inside), which was adjusted for the numbers of PPIs above the score threshold (i.e. loops per PPI). The number of PPIs for the complete K12 chromosomal dataset was negatively correlated with the combined score threshold $\left(r^{2}=0.964\right)$, as was the loops per PPI $\left(r^{2}=0.905\right)$, so the chromosomal loops per PPI was used as a baseline for different score thresholds.

\section{Operon gene homology search approach}

Homology searches for each fim operon gene were implemented using the NCTC13441 annotation coordinates to extract the corresponding sequence with SAMtools v1.9 and align each gene to the 4071 ST131 assemblies [60] with BLAST v2.2.31, processed with R packages Tidyverse v1.2.1 and Dplyr v0.8.3. For all operons, minor individual gene partial matches or losses were not examined due to the large number of samples and lack of consistent patterns for rare combinations. Results for amplified genes were restricted to those with prevalence $>1 \%$. The CDS of fimB is $600 \mathrm{bp}$, and with the ISEc55 insertion the region typically spanned 2493 bp. NCTC13441 has only three pap genes (papIBA) and lacks any $u c l$ or pil genes, so the pil genes were from pEK204. PilI and pilJ encoding IncI1 conjugal 
transfer proteins were mainly absent with no clear association with the other pil genes, and so were not examined here. PilV encoding a pilus tip adhesin had $>1$ copy in 292 assemblies, as expected for a locus rearranged to change pilus binding specificity [153]. The sequences for the four genes in the $5 \mathrm{~Kb} \mathrm{ucl}$ operon were determined from $E$. coli 83972 (CP001671): major subunit (uclA), chaperone (uclB), usher (uclC) and adhesin (uclD). E. coli UTI89's chromosome (CP000243) and plasmid (CP000244) [111] were used to get the pap genes.

\section{Funding information}

This work was funded by a DCU O'Hare Ph.D. fellowship and a DCU Enhancing Performance grant.

\section{Author contributions}

Conceptualisation, A. D., A. R. and T. D; Software, Validation, Investigation and Visualisation, A. D., A. R., H. A., B. A., L. C., K. E., L. M., M. N., N. T., S. P., G. S., C. S., Z. V. and C. W; Methodology, A. D., A. R., N. T. and T. D; Writing - Original Draft Preparation, A. D., N. T., A. R. and T. D; Writing - Review \& Editing, A. D., A. R. and T. D; Supervision and Project Administration, A. D., A. R. and T. D. Funding, A. D. and T. D.

\section{Conflicts of interest}

The authors declare that there are no conflicts of interest.

\section{References}

1. Gibson MK, Wang B, Ahmadi S, Burnham C-AD, Tarr PI et al. Developmental dynamics of the preterm infant gut microbiota and antibiotic resistome. Nature Microbiology 2016;1:16024.

2. Ben Zakour NL, Alsheikh-Hussain AS, Ashcroft MM, Khanh Nhu NT, Roberts LW et al. Sequential acquisition of virulence and fluoroquinolone resistance has shaped the evolution of Escherichia coli ST131. mBio 2016;7:e00347.

3. Calhau V, Ribeiro G, Mendonça N, Da Silva GJ. Prevalent combination of virulence and plasmidic-encoded resistance in ST 131 Escherichia coli strains. Virulence 2013:4:726-729.

4. Van der Bij AK, Peirano G, Pitondo-Silva A, Pitout JD. The presence of genes encoding for different virulence factors in clonally related Escherichia coli that produce CTX-Ms. Diagn Microbiol Infect Dis 2012;72:297-302.

5. Goswami C, Fox S, Holden M, Connor M, Leanord A et al. Genetic analysis of invasive Escherichia coli in Scotland reveals determinants of healthcare-associated versus community-acquired infections. Microb Genom 2018;4.

6. Poolman JT, Wacker M. Extraintestinal pathogenic Escherichia coli, a common human pathogen: challenges for vaccine development and progress in the field. J Infect Dis 2016;213:6-13.

7. The LD. Garrod Lecture: preparing for the black swans of resistance. J Antimicrob Chemother 2018;2018:2907-2915.

8. Banerjee R, Johnson JR. A new clone sweeps clean: the enigmatic emergence of Escherichia coli sequence type 131. Antimicrob Agents Chemother 2014;58:4997-5004.

9. Pitout JDD, DeVinney R. Escherichia coli ST131: a multidrugresistant clone primed for global domination. F1000Research 2017:6:195

10. Forde BM, Ben Zakour NL, Stanton-Cook M, Phan M-D, Totsika M et al. The complete genome sequence of Escherichia coli EC958: a high quality reference sequence for the globally disseminated multidrug resistant E. coli 025b:H4-ST131 clone. PLoS One 2014:9:e104400.

11. McNally A, Oren Y, Kelly D, Pascoe B, Dunn S et al. Combined analysis of variation in core, accessory and regulatory genome regions provides a super-resolution view into the evolution of bacterial populations. PLoS Genet 2016;12:1006280.
12. Kuehn MJ, Heuser J, Normark S, Hultgren SJ. P pili in uropathogenic E. coli are composite fibres with distinct fibrillar adhesive tips. Nature 1992;356:252-255.

13. Connell I, Agace W, Klemm P, Schembri M, Mărild S et al. Type 1 fimbrial expression enhances Escherichia coli virulence for the urinary tract. Proc Natl Acad Sci U S A 1996:93:9827-9832.

14. Martinez JJ, Mulvey MA, Schilling JD, Pinkner JS, Hultgren SJ. Type 1 pilus-mediated bacterial invasion of bladder epithelial cells. Embo J 2000;19:2803-2812.

15. Selvarangan R, Goluszko $P$, Singhal J, Carnoy C, Moseley $\mathrm{S}$ et al. Interaction of Dr adhesin with collagen type IV is a critical step in Escherichia coli renal persistence. Infect Immun 2004:72:4827-4835.

16. Price LB, Johnson JR, Aziz M, Clabots C, Johnston B et al. The epidemic of extended-spectrum- $\beta$-lactamase-producing Escherichia coli ST131 is driven by a single highly pathogenic subclone, H30-Rx. mBio 2013:4:e00377-13.

17. Petty NK, Ben Zakour NL, Stanton-Cook M, Skippington E, Totsika M et al. Global dissemination of a multidrug resistant Escherichia coli clone. Proc Natl Acad Sci U S A 2014:111:5694-5699.

18. Bloch CA, Orndorff PE. Impaired colonization by and full invasiveness of Escherichia coli K1 bearing a site-directed mutation in the type 1 pilin gene. Infect Immun 1990;58:275-278.

19. Totsika M, Kostakioti M, Hannan TJ, Upton M, Beatson SA et al. A FimH inhibitor prevents acute bladder infection and treats chronic cystitis caused by multidrug-resistant uropathogenic Escherichia coli ST131. J Infect Dis 2013;208:921-928.

20. Sarkar S, Vagenas D, Schembri MA, Totsika M. Biofilm formation by multidrug resistant Escherichia coli ST131 is dependent on type 1 fimbriae and assay conditions. Pathog Dis 2016;74:ftw013.

21. Bahrani-Mougeot FK, Buckles EL, Lockatell CV, Hebel JR, Johnson DE et al. Type 1 fimbriae and extracellular polysaccharides are preeminent uropathogenic Escherichia coli virulence determinants in the murine urinary tract. Mol Microbiol 2002;45:1079-1093.

22. Bäumler AJ, Sperandio V. Interactions between the microbiota and pathogenic bacteria in the gut. Nature 2016;535:85-93.

23. Bittinger Ket al. Bacterial colonization reprograms the neonatal gut metabolome. Nat Microbiol 2020.

24. Conway T, Cohen PS. Commensal and Pathogenic Escherichia coli Metabolism in the Gut. Microbiol Spectr 2015;3.

25. Hudault S, Guignot J, Servin AL. Escherichia coli strains colonising the gastrointestinal tract protect germfree mice against Salmonella typhimurium infection. Gut 2001;49:47-55.

26. Li G, Bielicki JA, Islam MS, Berezin EN et al. Towards understanding global patterns of antimicrobial use and resistance in neonatal sepsis: insights from the NeoAMR network. Arch Dis Child 2020;105:26-31.

27. Groussin Met al. Industrialization is associated with elevated rates of horizontal gene transfer in the human microbiome. BioRxiv 2020.

28. Gurnee EA, Ndao IM, Johnson JR, Johnston BD, Gonzalez MD et al. Gut colonization of healthy children and their mothers with pathogenic Ciprofloxacin-resistant Escherichia coli. J Infect Dis 2015;212:1862-1868

29. Yamamoto S, Tsukamoto T, Terai A, Kurazono H, Takeda $\mathrm{Y}$ et al. Genetic evidence supporting the fecal-perineal-urethral hypothesis in cystitis caused by Escherichia coli. J Urol 1997;157:1127-1129.

30. Rodríguez-Revuelta MJ, López-Cerero L, Serrano L, LunaLagares S, Pascual A et al. Duration of colonization by extendedspectrum $\beta$-lactamase-producing Enterobacteriaceae in healthy newborns and associated risk factors: a prospective cohort study. Open Forum Infect Dis 2018;5:ofy312.

31. Roemhild R, Linkevicius M, Andersson DI. Molecular mechanisms of collateral sensitivity to the antibiotic nitrofurantoin. PLoS Biol 2020;18:e3000612. 
32. Russell JTet al. Antibiotics may influence gut microbiome signaling to the brain in preterm neonates. BioRxiv 2020.

33. ECDC, European Centre for Disease Prevention and Control. European Centre for Disease Prevention and Control. Antimicrobial resistance surveillance in Europe 2015. Annual Report of the European Antimicrobial Resistance Surveillance Network (EARSNet). Stockholm: ECDC; 2017.

34. Findlay J, Gould VC, North P, Bowker KE, Williams MO et al. Characterization of cefotaxime-resistant urinary Escherichia coli from primary care in south-west England 2017-18. J Antimicrob Chemother 2020;75:65-71.

35. Mathers AJ, Peirano G, Pitout JD. The role of epidemic resistance plasmids and international high-risk clones in the spread of multidrug-resistant Enterobacteriaceae. Clin Microbiol Rev 2015;28:565-591.

36. Pitout JD, Laupland KB. Extended-spectrum $\beta$-lactamaseproducing Enterobacteriaceae: an emerging public-health concern. Lancet Infect Dis 2008;8:159-166.

37. Stokes HW, Gillings MR. Gene flow, mobile genetic elements and the recruitment of antibiotic resistance genes into gram-negative pathogens. FEMS Microbiol Rev 2011:35:790-819.

38. von Wintersdorff $\mathrm{CJH}$, Penders J, van Niekerk JM, Mills ND, Majumder $\mathrm{S}$ et al. Dissemination of antimicrobial resistance in microbial ecosystems through horizontal gene transfer. Front Microbiol 2016;7:173.

39. Goldstone RJ, Smith DGE. A population genomics approach to exploiting the accessory 'resistome' of Escherichia coli. Microb Genom 2017:3:e000108.

40. Baraniak A, Fiett J, Hryniewicz W, Nordmann P, Gniadkowski M. Ceftazidime-hydrolysing CTX-M-15 extended-spectrum betalactamase (ESBL) in Poland. J Antimicrob Chemother 2002; 50:393-396.

41. Pehrsson EC, Tsukayama P, Patel S, Mejía-Bautista M, SosaSoto $\mathrm{G}$ et al. Interconnected microbiomes and resistomes in lowincome human habitats. Nature 2016;533:212-216.

42. Durrant MG, Li MM, Siranosian BA, Montgomery SB, Bhatt AS. A bioinformatic analysis of integrative mobile genetic elements highlights their role in bacterial adaptation. Cell Host Microbe 2020;27:140-153.

43. Cerqueira GC, Earl AM, Ernst CM, Grad YH, Dekker JP et al. Multiinstitute analysis of carbapenem resistance reveals remarkable diversity, unexplained mechanisms, and limited clonal outbreaks. Proc Natl Acad Sci U S A 2017;114:1135-1140.

44. Hazen TH, Mettus R, McElheny CL, Bowler SL, Nagaraj S et al. Diversity among blaKPC-containing plasmids in Escherichia coli and other bacterial species isolated from the same patients. Sci Rep 2018;8:10291.

45. Kwong JC, Lane CR, Romanes F, Gonçalves da Silva A, Easton M et al. Translating genomics into practice for real-time surveillance and response to carbapenemase-producing Enterobacteriaceae: evidence from a complex multi-institutional KPC outbreak. PeerJ 2018;6:e4210.

46. Bosch T, Lutgens SPM, Hermans MHA, Wever PC, Schneeberger PM et al. Outbreak of NDM-1-Producing Klebsiella pneumoniae in a Dutch Hospital, with Interspecies Transfer of the Resistance Plasmid and Unexpected Occurrence in Unrelated Health Care Centers. J Clin Microbiol 2017;55:2380-2390.

47. Jamrozy D, Coll F, Mather AE, Harris SR, Harrison EM et al. Evolution of mobile genetic element composition in an epidemic methicillin-resistant Staphylococcus aureus: temporal changes correlated with frequent loss and gain events. BMC Genomics 2017; 18:684

48. Martin J, Phan HTT, Findlay J, Stoesser N, Pankhurst L et al. Covert dissemination of carbapenemase-producing Klebsiella pneumoniae (KPC) in a successfully controlled outbreak: long- and short-read whole-genome sequencing demonstrate multiple genetic modes of transmission. J Antimicrob Chemother 2017;72:3025-3034.
49. Smet A, Rasschaert G, Martel A, Persoons D, Dewulf J et al. In situ ESBL conjugation from avian to human Escherichia coli during cefotaxime administration. J Appl Microbiol 2011;110:541-549.

50. Ludden C, Decano AG, Jamrozy D, Pickard D, Morris D et al. Genomic surveillance of Escherichia coli ST131 identifies local expansion and serial replacement of subclones. Microb Genom 2020;6.

51. McNally A, Kallonen T, Connor C, Abudahab K, Aanensen DM et al. Diversification of Colonization Factors in a Multidrug-Resistant Escherichia coli Lineage Evolving under Negative FrequencyDependent Selection. MBio 2019;10:e00644-19.

52. Decano AG, Ludden C, Feltwell T, Judge K, Parkhill J et al. Complete assembly of Escherichia coli ST131 genomes using long reads demonstrates antibiotic resistance gene variation within diverse plasmid and chromosomal contexts. mSphere 2019:4:e00130-19.

53. Ny S, Sandegren L, Salemi M, Giske CG. Genome and plasmid diversity of extended-spectrum $\beta$-lactamase-producing Escherichia coli ST131 - tracking phylogenetic trajectories with Bayesian inference. Sci Rep 2019:9:10291.

54. Kallonen T, Brodrick HJ, Harris SR, Corander J, Brown NM et al. Systematic longitudinal survey of invasive Escherichia coli in England demonstrates a stable population structure only transiently disturbed by the emergence of ST131. Genome Res 2017:27:1437-1449.

55. Johnson JR, Davis G, Clabots C, Johnston BD, Porter S et al. Household Clustering of Escherichia coli Sequence Type 131 Clinical and Fecal Isolates According to Whole Genome Sequence Analysis. Open Forum Infect Dis 2016:3:ofw129.

56. Carattoli A. Resistance plasmid families in Enterobacteriaceae. Antimicrob Agents Chemother 2009;53:2227-2238.

57. Nicolas-Chanoine MH, Blanco J, Leflon-Guibout V, Demarty R, Alonso MP et al. Intercontinental emergence of Escherichia coli clone 025:H4-ST131 producing CTX-M-15. J Antimicrob Chemother 2008;61:273-281.

58. Nicolas-Chanoine MH, Bertrand X, Madec JY. Escherichia coli ST131, an intriguing clonal group. Clin Microbiol Rev 2014;27:543-574.

59. Woodford N, Carattoli A, Karisik E, Underwood A, Ellington MJ et al. Complete nucleotide sequences of plasmids pEK204, pEK499, and pEK516, encoding CTX-M enzymes in three major Escherichia coli lineages from the United Kingdom, all belonging to the international 025:H4-ST131 clone. Antimicrob Agents Chemother 2009:53:4472-4482.

60. Phan MD, Forde BM, Peters KM, Sarkar S, Hancock S et al. Molecular characterization of a multidrug resistance IncF plasmid from the globally disseminated Escherichia coli ST131 clone. PLoS One 2015;10:e0122369.

61. Decano AG, Downing T. An Escherichia coli ST131 pangenome atlas reveals population structure and evolution across 4,071 isolates. Sci Rep 2019;9:17394

62. Goswami C, Fox S, Holden MTG, Connor M, Leanord A et al. Origin, maintenance and spread of antibiotic resistance genes within plasmids and chromosomes of bloodstream isolates of Escherichia coli. Microb Genom 2020;6.

63. Jørgensen SB, Søraas A, Sundsfjord A, Liestøl K, Leegaard TM et al. Fecal carriage of extended spectrum $\beta$-lactamase producing Escherichia coli and Klebsiella pneumoniae after urinary tract infection - a three year prospective cohort study. PLoS One 2017;12:e0173510.

64. Coyne MJ, Zitomersky NL, McGuire AM, Earl AM, Comstock LE. Evidence of extensive DNA transfer between bacteroidales species within the human gut. mBio 2014;5:e01305-01314.

65. Zhao S. Adaptive evolution within the gut microbiome of individual people. BioRxiv 2017.

66. Bishara A. Strain-resolved microbiome sequencing reveals mobile elements that drive bacterial competition on a clinical timescale. BioRxiv. 
67. Knudsen PK, Gammelsrud KW, Alfsnes K, Steinbakk M, Abrahamsen TG et al. Transfer of a bla CTX-M-1-carrying plasmid between different Escherichia coli strains within the human gut explored by whole genome sequencing analyses. Sci Rep 2018:8:280

68. Göttig S, Gruber TM, Stecher B, Wichelhaus TA, Kempf VAJ. In vivo horizontal gene transfer of the carbapenemase OXA-48 during a nosocomial outbreak. Clin Infect Dis 2015;60:1808-1815.

69. Willemsen I, van Esser J, Kluytmans-van den Bergh M, Zhou K, Rossen JW et al. Retrospective identification of a previously undetected clinical case of OXA-48-producing $K$. pneumoniae and E. coli: the importance of adequate detection guidelines. Infection 2016:44:107-110.

70. Evans DRet al. Systematic detection of horizontal gene transfer across genera among multidrug-resistant bacteria in a single Hospital. Elife 2020.

71. Trobos M, Lester CH, Olsen JE, Frimodt-Møller N, Hammerum AM. Natural transfer of sulphonamide and ampicillin resistance between Escherichia coli residing in the human intestine. J Antimicrob Chemother 2009;63:80-86.

72. Karami N, Martner A, Enne VI, Swerkersson S, Adlerberth I, Wold AE et al. Transfer of an ampicillin resistance gene between two Escherichia coli strains in the bowel microbiota of an infant treated with antibiotics. J Antimicrob Chemother 2007:60:1142-1145.

73. Warnes SL, Highmore CJ, Keevil CW. Horizontal transfer of antibiotic resistance genes on abiotic touch surfaces: implications for public health. mBio 2012;3:e00489-12.

74. Andersson P, Engberg I, Lidin-Janson G, Lincoln K, Hull R et al. Persistence of Escherichia coli bacteriuria is not determined by bacterial adherence. Infect Immun 1991:59:2915-2921.

75. Hunt M, Mather AE, Sánchez-Busó L, Page AJ, Parkhill J et al. ARIBA: rapid antimicrobial resistance genotyping directly from sequencing reads. Microb Genom 2017;3:e000131.

76. Jia B, Raphenya AR, Alcock B, Waglechner N, Guo P et al. Card 2017: expansion and model-centric curation of the comprehensive antibiotic resistance database. Nucleic Acids Res 2017:45:D566-D573.

77. Rowe WPM, Winn MD. Indexed variation graphs for efficient and accurate resistome profiling. Bioinformatics 2018:34:3601-3608.

78. Phan MD, Bottomley AL, Peters KM, Harry EJ, Schembri MA. Uncovering novel susceptibility targets to enhance the efficacy of third-generation cephalosporins against ESBL-producing uropathogenic Escherichia coli. J Antimicrob Chemother 2020:dkaa023

79. Merlin TL, Davis GE, Anderson WL, Moyzis RK, Griffith JK. Aminoglycoside uptake increased by Tet gene expression. Antimicrob Agents Chemother 1989:33:1549-1552.

80. Stavropoulos TA, Strathdee CA. Expression of the tetA(C) tetracycline efflux pump in Escherichia coli confers osmotic sensitivity. FEMS Microbiol. Lett;1000:147-150.

81. Heng J, Zhao Y, Liu M, Liu Y, Fan J et al. Substrate-bound structure of the E. coli multidrug resistance transporter MdfA. Cell Res 2015;25:1060-1073.

82. Nguyen-Distèche $M$, Fraipont $C$, Buddelmeijer $N$, Nanninga $N$. The structure and function of Escherichia coli penicillin-binding protein 3. Cell Mol Life Sci 1998;54:309-316.

83. Nakamura M, Maruyama IN, Soma M, Kato J-ichi, Suzuki H et al. On the process of cellular division in Escherichia coli: nucleotide sequence of the gene for penicillin-binding protein 3. Molec Gen Genet 1983:191:1-9

84. Sun J, Deng Z, Yan A. Bacterial multidrug efflux pumps: mechanisms, physiology and pharmacological exploitations. Biochem Biophys Res Commun 2014:453:254-267.

85. Curtis NA, Eisenstadt RL, Turner KA, White AJ. Inhibition of penicillin-binding protein 3 of Escherichia coli K-12. Effects upon growth, viability and outer membrane barrier function. J Antimicrob Chemother 1985;16:287-296.
86. Carattoli A, Zankari E, García-Fernández A, Voldby Larsen M, Lund 0 et al. In Silico Detection and Typing of Plasmids using PlasmidFinder and Plasmid Multilocus Sequence Typing. Antimicrob Agents Chemother 2014;58:3895-3903.

87. Toh H, Oshima K, Toyoda A, Ogura Y, Ooka T et al. Complete genome sequence of the wild-type commensal Escherichia coli strain SE15, belonging to phylogenetic group B2. J Bacteriol 2010;192:1165-1166

88. Johnson JR, Porter S, Thuras P, Castanheira M. Epidemic emergence in the United States of Escherichia coli sequence type 131H30 (ST131-H30), 2000 to 2009. Antimicrob Agents Chemother 2017;61:e00732-17.

89. Karisik E, Ellington MJ, Pike R, Warren RE, Livermore DM. Molecular characterization of plasmids encoding CTX-M-15 -lactamases from Escherichia coli strains in the United Kingdom. $J$ Antimicrob Chemother 2006;58:665-668.

90. Dudley EG, Abe C, Ghigo JM, Latour-Lambert P, Hormazabal JC et al. An Incl1 plasmid contributes to the adherence of the atypical enteroaggregative Escherichia coli strain C1096 to cultured cells and abiotic surfaces. Infect Immun 2006;74:2102-2114.

91. Dhanji H, Doumith M, Hope R, Livermore DM, Woodford N. ISEcp1mediated transposition of linked blaCTX-M-3 and blaTEM$1 \mathrm{~b}$ from the Incl1 plasmid pEK204 found in clinical isolates of Escherichia coli from Belfast, UK. J Antimicrob Chemother 2011:66:2263-2265.

92. Runyen-Janecky LJ, Hong M, Payne SM. The virulence plasmidencoded impCAB operon enhances survival and induced mutagenesis in Shigellaflexneri after exposure to UV radiation. Infect Immun 1999;67:1415-1423.

93. Akiba M, Sekizuka T, Yamashita A, Kuroda M, Fujii Y et al. Distribution and relationships of antimicrobial resistance determinants among extended-spectrum-cephalosporin-resistant or carbapenem-resistant Escherichia coli isolates from rivers and sewage treatment plants in India. Antimicrob Agents Chemother 2016;60:2972-2980.

94. Purves K, Macintyre L, Brennan D, Hreggviðsson G, Kuttner E et al. Using molecular networking for microbial secondary metabolite bioprospecting. Metabolites 2016;6:2.

95. Typas A, Sourjik V. Bacterial protein networks: properties and functions. Nat Rev Microbiol 2015;13:559-572.

96. Kirschner M, Gerhart J. Evolvability. Proc Natl Acad Sci U S A 1998:95:8420-8427.

97. Szklarczyk D, Gable AL, Lyon D, Junge A, Wyder S et al. String v11: protein-protein association networks with increased coverage, supporting functional discovery in genome-wide experimental datasets. Nucleic Acids Res 2019:47:D607-D613.

98. Miryala SK, Ramaiah S. Exploring the multi-drug resistance in Escherichia coli 0157:H7 by gene interaction network: A systems biology approach. Genomics 2019;111:958-965.

99. Zong Z. Complete sequence of pJIE186-2, a plasmid carrying multiple virulence factors from a sequence type 131 Escherichia coli 025 strain. Antimicrob Agents Chemother 2013;57:597-600.

100. Holden N, Totsika M, Dixon L, Catherwood K, Gally DL. Regulation of P-Fimbrial phase variation frequencies in Escherichia coli CFT073. Infect Immun 2007:75:3325-3334.

101. Clark G, Paszkiewicz K, Hale J, Weston V, Constantinidou C et al. Genomic analysis uncovers a phenotypically diverse but genetically homogeneous Escherichia coli ST131 clone circulating in unrelated urinary tract infections. J Antimicrob Chemother 2012;67:868-877.

102. Spaulding CN, Klein RD, Ruer S, Kau AL, Schreiber HL et al. Selective depletion of uropathogenic $E$. coli from the gut by a FimH antagonist. Nature 2017;546:528-532.

103. Xia Y, Gally D, Forsman-Semb K, Uhlin BE. Regulatory crosstalk between adhesin operons in Escherichia coli: inhibition of type 1 fimbriae expression by the PapB protein. Embo $J$ 2000;19:1450-1457. 
104. Snyder JA, Haugen BJ, Lockatell CV, Maroncle N, Hagan EC et al. Coordinate expression of fimbriae in uropathogenic Escherichia coli. Infect Immun 2005;73:7588-7596.

105. Forsman K, Göransson M, Uhlin BE. Autoregulation and multiple DNA interactions by a transcriptional regulatory protein in $E$. coli pili biogenesis. Embo J 1989:8:1271-1277.

106. Holden NJ, Totsika M, Mahler E, Roe AJ, Catherwood $\mathrm{K}$ et al. Demonstration of regulatory cross-talk between $\mathrm{P}$ fimbriae and type 1 fimbriae in uropathogenic Escherichia coli. Microbiology 2006:152:1143-1153.

107. Brzuszkiewicz $E$, Brüggemann $H$, Liesegang $H$, Emmerth $M$, Olschläger $T$ et al. How to become a uropathogen: comparative genomic analysis of extraintestinal pathogenic Escherichia coli strains. Proc Natl Acad Sci U S A 2006;103:12879-12884.

108. Welch RA, Burland V, Plunkett G, Redford P, Roesch $P$ et al. Extensive mosaic structure revealed by the complete genome sequence of uropathogenic Escherichia coli. Proc Natl Acad Sci U S A 2002:99:17020-17024.

109. Lillington J, Geibel S, Waksman G. Biogenesis and adhesion of type 1 and P pili. Biochim Biophys Acta 2014;1840:2783-2793.

110. Forsberg KJ, Reyes A, Wang B, Selleck EM, Sommer MO et al. The shared antibiotic resistome of soil bacteria and human pathogens. Science 2012:337:1107-1111.

111. Chen SL, Hung C-S, Xu J, Reigstad CS, Magrini V et al. Identification of genes subject to positive selection in uropathogenic strains of Escherichia coli: a comparative genomics approach. Proc Natl Acad Sci U S A 2006;103:5977-5982.

112. Tenaillon O, Skurnik D, Picard B, Denamur E. The population genetics of commensal Escherichia coli. Nat Rev Microbiol 2010;8:207-217.

113. Didelot X, Méric G, Falush D, Darling AE. Impact of homologous and non-homologous recombination in the genomic evolution of Escherichia coli. BMC Genomics 2012;13:256.

114. Dixit PD, Pang TY, Studier FW, Maslov S. Recombinant transfer in the basic genome of Escherichia coli. Proc Natl Acad Sci U S A 2015;112:9070-9075.

115. Tchesnokova V, Radey M, Chattopadhyay S, Larson L, Weaver JL et al. Pandemic fluoroquinolone resistant Escherichia coli clone ST1193 emerged via simultaneous homologous recombinations in 11 gene loci. Proc Natl Acad Sci U S A 2019;116:14740-14748.

116. Smillie CS, Smith MB, Friedman J, Cordero OX, David LA et al. Ecology drives a global network of gene exchange connecting the human microbiome. Nature 2011;480:241-244.

117. Lloyd-Price J, Mahurkar A, Rahnavard G, Crabtree J, Orvis J et al. Strains, functions and dynamics in the expanded human microbiome project. Nature 2017;550:61-66.

118. Tamburini FB, Andermann TM, Tkachenko E, Senchyna F, Banaei $\mathrm{N}$ et al. Precision identification of diverse bloodstream pathogens in the gut microbiome. Nat Med 2018:24:1809-1814.

119. Sundén F, Håkansson L, Ljunggren E, Wullt B. Escherichia coli 83972 bacteriuria protects against recurrent lower urinary tract infections in patients with incomplete bladder emptying. J Urol 2010;184:179-185.

120. Sundén F, Håkansson L, Ljunggren E, Wullt B. Bacterial interference--is deliberate colonization with Escherichia coli 83972 an alternative treatment for patients with recurrent urinary tract infection? Int J Antimicrob Agents 2006;28 Suppl 1:26-29.

121. Watts RE, Tan CK, Ulett GC, Carey AJ, Totsika M et al. Escherichia coli 83972 expressing a P fimbriae oligosaccharide receptor mimic impairs adhesion of uropathogenic E. coli. J Infect Dis 2012;206:1242-1249.

122. Zdziarski J, Brzuszkiewicz E, Wullt B, Liesegang H, Biran D et al. Host imprints on bacterial genomes--rapid, divergent evolution in individual patients. PLoS Pathog 2010;6:e1001078.

123. Duprilot Met al. Success of Escherichia coli O25b:H4 ST131 clade C associated with a decrease in virulence. BioRxiv 2019.
124. Mora A, Dahbi G, López C, Mamani R, Marzoa J et al. Virulence patterns in a murine sepsis model of ST131 Escherichia coli clinical isolates belonging to serotypes 025b:H4 and 016:H5 are associated to specific virotypes. PLoS One 2014;9:e87025.

125. Fondi M, Karkman A, Tamminen MV, Bosi E, Virta M et al. "Every gene is everywhere but the environment selects": Global Geolocalization of gene sharing in environmental samples through network analysis. Genome Biol Evol 2016;8:1388-1400.

126. Downing T. Tackling drug resistant infection outbreaks of Global Pandemic Escherichia coli ST131 using evolutionary and epidemiological genomics. Microorganisms 2015;3:236-267.

127. Leggett RM, Alcon-Giner C, Heavens D, Caim S, Brook TC et al. Rapid MinION profiling of preterm microbiota and antimicrobialresistant pathogens. Nat Microbiol 2020;5:430-442.

128. Smith H, Bossers A, Harders F, Wu G, Woodford N et al. Characterization of epidemic Incl1-l $\gamma$ plasmids harboring Ambler class $\mathrm{A}$ and $\mathrm{C}$ genes in Escherichia coli and Salmonella enterica from animals and humans. Antimicrob Agents Chemother 2015:59:5357-5365.

129. Rozwandowicz M, Brouwer MSM, Fischer J, Wagenaar JA Gonzalez-Zorn B et al. Plasmids carrying antimicrobial resistance genes in Enterobacteriaceae. J Antimicrob Chemother 2018;73:1121-1137.

130. Rodríguez-Navarro J, Miró E, Brown-Jaque M, Hurtado JC Moreno A et al. Comparison of Commensal and Clinical Isolates for Diversity of Plasmids in Escherichia coli and Klebsiella pneumoniae. Antimicrob Agents Chemother 2020;64:pii:e02064-19.

131. Dimitriu T, Medaney F, Amanatidou E, Forsyth J, Ellis RJ et al. Negative frequency dependent selection on plasmid carriage and low fitness costs maintain extended spectrum $\beta$-lactamases in Escherichia coli. Sci Rep 2019:9:17211.

132. Totsika M, Beatson SA, Sarkar S, Phan M-D, Petty NK et al. Insights into a multidrug resistant Escherichia coli pathogen of the globally disseminated ST131 lineage: genome analysis and virulence mechanisms. PLoS One 2011;6:e26578.

133. Schembri MA, Zakour NL, Phan MD, Forde BM, Stanton-Cook M et al. Molecular Characterization of the Multidrug Resistant Escherichia coli ST131 Clone. Pathogens 2015;4:422-430.

134. Wurpel DJ, Totsika M, Allsopp LP, Webb RI, Moriel DG et al. Comparative proteomics of uropathogenic Escherichia coli during growth in human urine identify UCA-like (UCL) fimbriae as an adherence factor involved in biofilm formation and binding to uroepithelial cells. J Proteomics 2016;131:177-189.

135. Lane MC, Mobley HL. Role of P-fimbrial-mediated adherence in pyelonephritis and persistence of uropathogenic Escherichia coli (UPEC) in the mammalian kidney. Kidney Int 2007;72:19-25.

136. Gunther NW, Lockatell V, Johnson DE, Mobley HL. In vivo dynamics of type 1 fimbria regulation in uropathogenic Escherichia coli during experimental urinary tract infection. Infect Immun 2001;69:2838-2846.

137. Holden NJ, Uhlin BE, Gally DL. PapB paralogues and their effect on the phase variation of type 1 fimbriae in Escherichia coli. Mol Microbiol 2001;42:319-330.

138. Holden NJ, Gally DL. Switches, cross-talk and memory in Escherichia coli adherence. J Med Microbiol 2004:53:585-593.

139. Whitmer GR, Moorthy G, Arshad M. The pandemic Escherichia coli sequence type 131 strain is acquired even in the absence of antibiotic exposure. PLoS Pathog 2019;15:e1008162.

140. NIH HMP Working Group, Peterson J, Garges S, Giovanni M, Mclnnes P et al. The NIH human microbiome project. Genome Res 2009:19:2317-2323.

141. Rudick CN, Taylor AK, Yaggie RE, Schaeffer AJ, Klumpp DJ. Asymptomatic bacteriuria Escherichia coli are live biotherapeutics for UTI. PLoS One 2014;9:e109321-109329.

142. Hancock V, Seshasayee AS, Ussery DW, Luscombe NM, Klemm P. Transcriptomics and adaptive genomics of the asymptomatic bacteriuria Escherichia coli strain 83972. Mol Genet Genomics 2008;279:523-534. 
143. Floyd RV, Upton M, Hultgren SJ, Wray S, Burdyga TV et al. Escherichia coli-mediated impairment of ureteric contractility is uropathogenic E. coli specific. J Infect Dis 2012;206:1589-1596.

144. Bolger AM, Lohse M, Usadel B. Trimmomatic: a flexible trimmer for illumina sequence data. Bioinformatics 2014;30:2114-2120.

145. Li H, Handsaker B, Wysoker A, Fennell T, Ruan J et al. The sequence Alignment/Map format and SAMtools. Bioinformatics 2009;25:2078-2079.

146. Jones $\mathrm{P}$, Binns D, Chang H-Y, Fraser M, Li W et al. InterProScan 5: genome-scale protein function classification. Bioinformatics 2014:30:1236-1240.

147. Carver T, Berriman M, Tivey A, Patel C, Böhme U et al. Artemis and $A C T$ : viewing, annotating and comparing sequences stored in a relational database. Bioinformatics 2008;24:2672-2676.
148. Sievers F, Wilm A, Dineen D, Gibson TJ, Karplus K et al. Fast, scalable generation of high-quality protein multiple sequence alignments using Clustal omega. Mol Syst Biol 2011;7:539.

149. Nicolau M, Levine AJ, Carlsson G. Topology based data analysis identifies a subgroup of breast cancers with a unique mutational profile and excellent survival. Proc Natl Acad Sci U S A 2011:108:7265-7270.

150. Vietoris L. Über den höheren Zusammenhang kompakter Räume und eine Klasse von zusammenhangstreuen Abbildungen. Mathematische Annalen 1927;97:454-472.

151. Rahm A. HomologyLive 2019.

152. The LinBox Group. Exact linear algebra over the Integers and finite rings, version 1.1.6 2008.

153. Kim SR, Komano T. The plasmid R64 thin pilus identified as a type IV pilus. J Bacteriol 1997;179:3594-3603.

\section{Five reasons to publish your next article with a Microbiology Society journal}

1. The Microbiology Society is a not-for-profit organization.

2. We offer fast and rigorous peer review - average time to first decision is 4-6 weeks.

3. Our journals have a global readership with subscriptions held in research institutions around the world.

4. $80 \%$ of our authors rate our submission process as 'excellent' or 'very good'.

5. Your article will be published on an interactive journal platform with advanced metrics.

Find out more and submit your article at microbiologyresearch.org. 